abnormal splicing of the intracytoplasmic tail of the receptor.

How does leptin enter the brain, given that the blood-brain barrier is normally impervious to polypeptide hormones? The simple answer may be that, like insulin, it is transported into the brain by the choroid plexus; the intense expression of OB-R there suggests that is indeed the case. The high level of OB-R expression in the lungs and kidneys, sites of polypeptide hormone disposal, points to these tissues as the places where excess leptin is dealt with

The past year has provided other insights into the control of body weight. Prostaglandins of the $\mathbf{J}$ series have been identified as endogenous activators of peroxisome proliferator-activated receptors, so-called orphan nuclear receptors that are implicated in fat-cell homeosta$\operatorname{sis}^{13,14}$. The antidiabetic thiazolidinedione drugs have been found to act on gene transcription through this same nuclearreceptor signalling pathway, so providing a route for the control of metabolism in fat cells. Finally, in a paper published last week $^{15}$, Turton and colleagues have shown that injection into the brain of the neurotransmitter glucagon-like peptide 1 (GLP1) inhibits feeding in rats. The activity of GLP-1 can be blocked at its receptor by a natural antagonist called exendin, which augments the response to the appetite stimulant NPY. GLP-1 therefore appears to be a central mediator of satiety.

Much of course remains to be done. How is the biosynthesis and secretion of leptin controlled? Is the newly described protein indeed the true leptin receptor? How is the leptin signal transmitted to NPY and beyond? Does overeating with time disrupt leptin signalling? What is the precise role of GLP-1 and its receptor in satiety? And are other neurotransmitters involved?

These issues are no doubt being pursued with great vigour. Not least, at stake is a potential billion-dollar-a-year prize for molecular-level treatments for obesity. Such therapies might take the form of drugs that enhance leptin production or otherwise amplify the leptin signal.

James Scott is in the Department of Medicine, Royal Postgraduate Medical School, Hammersmith Hospital, Du Cane Road, London W12 ONN, UK.

\footnotetext{
. Zhang, Y. et al. Nature 372, 425-432 (1994).

. Tartaglia, L. A et al Cell 83, 1263-1127 (1995)

3. Considine, R.V. et al. J. clin. Invest. 95, 2986-2988 (1995)

Hamilton, B.S. et al. Nature Med. 1, 953-956 (1995)

5. Lonnqvist, F. et al. Nature Med. 1, 950-953 (1995)

6. Maffei, M. et al. Nature Med. 1, 1155-1161 (1995).

. Mink, T. J. Nature 372, 406-407 (1994).

Rink, T. J. Nature 372, 406-407 (1994).
Campfield, L. A. et al. Science 269, 546-549 (1995)

8. Campfield, L. A. et al. Science 269, 546-549 (1995).
9. Halaas, J. L. et al. Science 269, 543-546 (1995).

10. Pelleymounter, M. A. et al. Science 269, 540-543 (1995)

11. Saladin, R. et al. Nature 377, 527-529 (1995)

12. Stephens, T. W. et al. Nature 377, 530-532 (1995)

13. Forman, B. M. et al. Cell 83, 803-812 (1995)

14. Rameh, L. E et al. Cell 83, 821-830 (1995).

15. Turton, M. D. et al. Nature 379, 69-72 (1996)
}

\title{
Ediacarans in deep water
}

\section{Douglas Palmer}

Almost 50 years ago the first description of mysterious Precambrian fossils from the Ediacara Hills in Australia was published ${ }^{1}$. Subsequent discoveries from elsewhere in the world led to the definition of the socalled Ediacaran fauna of jellyfish-like organisms. These were globally distributed and apparently became extinct well before the beginning of the Cambrian period, here taken to be about 540 million years (Myr) ago, and the evolutionary 'explosion' of multicellular animals with shells. The fossils have been the subject of much discussion as regards their taxonomic affinities and evolutionary history.

Debate enters a fresh phase with the description by Crimes et $a l^{2}$ of new examples of Ediacaran fossils from deep-water deposits, some $510 \mathrm{Myr}^{\text {old }}{ }^{3}$, in County Wexford, Ireland. Taken together with a paper by Grotzinger and colleagues ${ }^{4}$, which provided dates for Namibian specimens from close to the Precambrian-Cambrian boundary, the finding may well be the death knell for the idea that the Ediacaran fauna was a failed evolutionary experiment. Moreover, the unusual preservation of the Irish fossils provides support for the view ${ }^{5}$ that, in life, the creatures were not softbodied but had a rigid outer wall unlike any extant group.

The Ediacara are dominated by a few forms, which look superficially like living jellyfish and seapens of the phylum Cnidaria. But these 'jellyfish' seem to lack certain anatomical details characteristic of living species, such as any clear indication of a mouth or gastric cavity, and their three-dimensional preservation as sediment-filled moulds has raised serious questions about their taxonomic affinities. The taphonomy, or mode of preservation, of such 'soft-bodied' organisms is a key issue. Most of the Ediacaran fossils have until now been found in sandstones originally laid down in shallow water. Somehow or other, the three-dimensional form of the medusoid-like fossils is generally preserved without substantial flattening but with the body shape infilled with sediment. No trace of tissue, mineralized or not, remains. The question is whether such preservation can be produced from tissues like those found in living medusoids, or whether it indicates that we are dealing with some quite different type of organism.

A feature of the Irish fossils is that they occur in turbiditic deposits laid down in deep water. There are two different medusoid-like taxa, both preserved as sedimentfilled moulds. The small $(2-8 \mathrm{~mm}$ diameter) discoid Nimbia occlusa fossils occur with similar orientation flat on a single bedding plane. The larger Ediacaria booleyi discs are more variable in size
(26-200 $\mathrm{mm}$ in diameter) and occur jumbled together at all angles within several successive strata.

The unfragmented preservation of the specimens shows that their body tissue was tough enough to resist being torn apart while being tumbled about in fast-moving, bottom-hugging, turbulent density currents - the submarine equivalent of a washing machine full of sand. Furthermore, entombment in density currents may be telling us something significant about the organisms' own density. Would modern jellyfish be buried in turbidite deposits like these? I doubt it, but there is clearly a need for more data on this score.

What few taphonomic experiments there have been on comparable soft-bodied living cnidarians show that, on decay, jellyfish tend to leave flat impressions. Indeed, it has been argued ${ }^{7}$ that the typical Ediacaran sandstone preservation is more akin to that found in plant fossils with cellulosestrengthened stem tissues. The Irish fossils, with their different sediment matrix, show that three-dimensional preservation of these organisms was not specific to shallowwater sandstones.

On the palaeobiology of the new specimens, Crimes et al. argue that the absence of any indication of a mouth is good evidence against a cnidarian affinity. But to my mind the jury must remain out on that question, especially in view of decay experiments ${ }^{8}$ on cnidaria which showed that such oral structures are not necessarily preserved in medusoids. Finally, it may be that the habitat of these Ediacaran 'medusoids' was the result of one of the earliest examples of competitive exclusion - as the authors point out, it looks as if they retreated from their original shallow-water niche into a deep-water refuge.

We are no doubt still seeing only the opening shots in the revived Ediacaran debate. On the taxonomic front, more information should come from detailed comparative study of the diagnostic features of the new fossils and other Ediacaran species; and we can hope for further, illuminating discoveries, especially in the beautifully preserved, flat-lying Late Precambrian strata of Namibia.

Douglas Palmer is at 31 Mawson Road, Cambridge CB1 2DZ, UK.

\footnotetext{
Sprigg, R. C. Trans. R. Soc. S. Aust. 71, 212-224 (1947) . Crimes, T. P., Insole, A. \& Williams, B. P. J. Geol. J. $\mathbf{3 0}$ 89-109 (1995).

3. Moczyolowska, M. \& Crimes, T. P. Geol J. 30, 111-128 (1995).

4. Grotzinger, J. P., Bowring, S.A., Saylor, B.Z. \& Kaufman, A.J. Science 270, 598-604 (1995).

5. Seilacher, A. J. Geol. Soc. Lond. 149, 607-613 (1992).

6. Briggs, D. E. G. Palaios (in the press)

7. Retallack, G. J. Paleobiology 20, 523-544 (1994).

8. Norris, R. D. Lethaia 22, 381-393 (1989)
} 